\title{
The Propagation of Edible Yams from Cuttings ${ }^{1}$
}

\author{
Eugenio Cabanillas and Franklin W. Martin ${ }^{2}$
}

\begin{abstract}
Simple techniques developed for rooting stem cuttings of sapogenin-bearing yams were tested with edible species and their varieties. Rooting began within 5 weeks after initiation of treatment or not at all. Species and varietal differences were evident. Cuttings of most $D$. alata varieties root freely, those of $D$. rutundata are intermediate, and those of $D$. esculenta and $D$. trifida are very difficult to root. Cuttings taken early in the season develop roots and shoots readily, but those taken later develop a small tuber and roots but often do not develop shoots. Very young cuttings or cuttings from the mature stem do not root as easily as cuttings of intermediate age.
\end{abstract}

\section{INTRODUCTION}

The edible yams (Dioscorea spp.) are propagated from tuber pieces, aerial tubers, and small underground tubers. These often contain preformed buds, but if not, the cambial layer can produce new buds if a portion of the surface of the tuber is included as part of the seed piece. The propagation from tubers means that the rate of propagation per season is limited. Furthermore, a portion of the marketable (edible) crop must be reserved each season for propagation of the new crop. Because of these limitations, the propagation of yams from stem cuttings has been investigated. Using one-node vine cuttings, it is possible to multiply selected materials by as much as several hundredfold in a single year.

The techniques of propagation of yams from stems of the non-edible sapogenin-bearing yams (2) have been developed principally by the investigators. Stem cuttings of $D$. belizensis were propagated satisfactorily by Blunden et al., (1) but cuttings of $D$. deltoidea and $D$. sylvatica failed. In $D$. floribunda and $D$. composita, the factors that influenced germination of cuttings were age of the leaf (young leaves rooted better than older leaves), season (cuttings were rooted more easily during the early part of the season), and treatment with hormones and fungicides (4). Several kinds of behavior were reported. Cuttings normally developed undifferentiated tubers at the axils of the leaves. Adventitious roots and new shoots then developed from such tissue. At times only the rudimentary tuber and roots developed. The newly formed plants had many of the characteristics of seedlings. The young vines were tender and slow

${ }^{1}$ Manuscript submitted to Editorial Board December 5, 1977.

${ }^{2}$ Agricultural Research Technician and Plant Geneticist, Mayagüez Institute of Tropical Agriculture, Southern Region, ARS, USDA, Mayagüez, P.R. 00708. 
growing and required about a year of juvenile growth before vigorous plants were established.

An unusual form of multiplication from stem cuttings was developed for D. spiculiflora Hemsl. The plantlet that originated at the node tended to multiply itself into several parallel stems that could be separated and repropagated indefinitely (6). This rosette type of growth is rare in Dioscorea.

Although the propagation of the edible yams from stem cuttings has been studied in several places, only two reports have been published. Njoku (5) tried three edible species, D. alata L., D. rotundata Poir, and D. dumentorum. The single-node cuttings were rooted in the laboratory in water or in potting soil. The development of the tuber, root, and shoot followed the pattern described above for the sapogenin-bearing species. Exposure of cuttings to long days promoted vine growth, while exposure to short-day lengths promoted growth of the tuber. Njoku concluded that the weakness of plants from cuttings prevented their use for commercial plantings.

Ferguson reviewed these studies (3), and discussed thoroughly the physiological principles involved. In addition, he added new data from his own observations. The first new tissue developed from yam cuttings is not root but probably stem tissue. Thus, the normal hormonal treatments useful in stimulating rooting may not be useful in stimulating the germination of cuttings of these species.

\section{MATERIALS AND METHODS}

The experimental material consisted of varieties of several species of yams collected from world-wide sources. These yams were grown under favorable conditions at the Mayagüez Institute of Tropical Agriculture, Mayagüez, Puerto Rico, and used for the several kinds of experiments reported. The most important varieties are identified in the various tables where they appear.

The technique for rooting cuttings was much the same as that used for rooting the cuttings of sapogenin-bearing yams (4). The rooting bed consisted of smooth particles of river gravel washed free of soil and sterilized periodically with $10 \%$ formalin. The bed was treated with mist spray regulated by clock to give $6 \mathrm{~s}$ of spray each min from 8:00 A.M. to 5:00 P.M. daily. Cuttings consisted of a single node, attached leaf or leaves, and about $1 / 3$ of the internode on each side of the node. The cuttings were placed in the gravel with the node and stem buried below the surface, and with the blade and part of the petiole supported above the gravel. Six weeks after planting, the cuttings were inspected and rated for root, tuber, and shoot formation.

Species and varieties were compared by making 100 cuttings of all ages 
early in the season. When particularly poor results were obtained, the trials were repeated.

The influence of age of leaf on the germination of cuttings was studied by removing long vines, discarding the very succulent tip, and cutting the vines to equal fourths, from which were obtained the youngest, oldest, and intermediate classes of cuttings. Seasonal influence on propagability was observed in cuttings of a mixture of ages taken each month during the growing season.

The influence of a commercial rooting agent (Rootone) $)^{3}$ dusted on the axils of the leaves before the mist treatment was also investigated.

\section{RESULTS}

Most cuttings placed in the propagating bed rooted rapidly. First roots were visible about 3 weeks after placement of the cuttings, and at 5 weeks the percentage of rooted cuttings neared a maximum. After 5 weeks very few of the cuttings that had not already rooted developed roots. Root development was normally preceded by the growth of undifferentiated tissue. However, this tissue was sometimes so insignificant in size that it was not evident to the eye. In all cases, healthy rooted cuttings developed a small tuber within a few weeks after rooting.

Species and varietal differences were seen with respect to the ability of cuttings to root (table 1). Varieties of $D$. alata were usually responsive. Varieties of $D$. rotundata were less responsive, and varieties of $D$. esculenta and $D$. trifida were usually difficult to root. However, cuttings of a few $D$. alata varieties also rooted very poorly.

Shoots arose from the newly formed tuber, not from the cutting itself. The shoot usually developed soon after the roots and tuber but was sometimes delayed, so that no shoot occurred after the season of normal dormancy. The small tubers all germinated regardless of whether a shoot had been produced the previous season. Varietal differences were evident with respect to this characteristic.

Season influenced the ability of cuttings of the variety Florido ( $D$. alata) to develop roots and shoots (table 2). The percentage of cuttings that rooted was not influenced materially by season. Nevertheless, only the cuttings taken very early produced shoots satisfactorily. The cuttings taken late in the season produced roots but did not produce shoots. This seasonal effect has been confirmed with other varieties. However, few show as drastic a seasonal effect as the selected variety.

In addition to season of the year, the relative age of the cutting on the

${ }^{3}$ Trade names are used in this publication solely for the purpose of providing specific information. Mention of a trade name does not constitute a guarantee or warranty of equipment or materials by the Agricultural Experiment Station of the University of Puerto Rico or an endorsement over other equipment or materials not mentioned. 
TABLE 1.-Typical rooting and shooting of stem cuttings of various species of yams after 6 weeks of mist spray treatment

\begin{tabular}{|c|c|c|c|c|}
\hline \multirow{2}{*}{$\begin{array}{l}\text { Accession } \\
\text { number }\end{array}$} & \multirow[b]{2}{*}{ Varieties } & \multirow{2}{*}{$\begin{array}{l}\text { Number of } \\
\text { cuttings }\end{array}$} & \multicolumn{2}{|c|}{ Percentage of cuttings } \\
\hline & & & With roots & $\begin{array}{l}\text { With roots } \\
\text { and shoots }\end{array}$ \\
\hline \multicolumn{5}{|c|}{ Dioscorea alata } \\
\hline 15211 & Debilidad & 35 & 54 & 18 \\
\hline 15376 & Lástima & 15 & 0 & 0 \\
\hline 15377 & Masi & 25 & 0 & 0 \\
\hline 15378 & Bandido & 25 & 0 & 0 \\
\hline 15383 & Winny & 25 & 48 & 4 \\
\hline 15384 & Toa & 25 & 0 & 0 \\
\hline 15385 & Bai & 25 & 0 & 0 \\
\hline 15386 & Minti & 30 & 2 & 0 \\
\hline 15389 & Banze & 29 & 17 & 13 \\
\hline 15391 & Yak & 30 & 16 & 0 \\
\hline 15475 & Belep & 30 & 80 & 50 \\
\hline 15476 & Bete & 10 & 0 & 0 \\
\hline 15477 & Masi & 28 & 21 & 0 \\
\hline 15478 & Bandido & 13 & 8 & 1i) \\
\hline 15503 & Double Feuille Violette & 25 & 76 & 60 \\
\hline 15506 & Nza Seguela & 34 & 85 & 50 \\
\hline 15507 & Bete Bete & 25 & 0 & 0 \\
\hline 15513 & Irene & 30 & 87 & 3 \\
\hline \multicolumn{5}{|c|}{ Discorea rotundata } \\
\hline 15483 & Lopka & 50 & 14 & 0 \\
\hline 15484 & Grosse Gaille Corrosel & 25 & 100 & $2 \pi$ \\
\hline 15485 & Grosse Caille 3 Mois & 25 & 0 & 0 \\
\hline 15487 & Saint Prix & 30 & 22 & 7 \\
\hline 15488 & Jeune & 35 & 0 & 0 \\
\hline 15490 & Vineo & 35 & 0 & 0 \\
\hline 15493 & Negro & 25 & 96 & 20 \\
\hline 15495 & Kangba & 25 & 44 & 0 \\
\hline 15497 & N'Detre & 25 & 0 & 0 \\
\hline 15498 & Douce & 30 & 60 & 14 \\
\hline \multicolumn{5}{|c|}{ Miscellaneous species } \\
\hline 14387 & D. esculenta & 25 & 0 & 0 \\
\hline 14388 & D. esculenta. & 30 & 0 & 0 \\
\hline 15480 & D. trifida & 26 & 0 & 0 \\
\hline 15481 & D. trifida & 10 & 0 & 0 \\
\hline 15482 & D. trifida & 12 & 0 & 0 \\
\hline 15499 & D. numularia & 50 & 40 & 8 \\
\hline
\end{tabular}

vine influenced rootability (table 3 ). Young cuttings from the tip of the vine did not root well, and those that rooted did not always shoot. Older, but not very old, cuttings were the best with respect to both rooting and shooting.

The hormonal treatment did not give consistent and reproducible results and appears to be unnecessary in germinating cuttings. 


\section{DISCUSSION AND CONCLUSIONS}

Some yam varieties can be multiplied very readily from stem cuttings. For those responsive varieties the most important part of the technique is to take cuttings at a very early stage in the growth of the plant when cuttings are most likely to succeed. Obviously old and damaged or very young cuttings should also be avoided, for they are unlikely to root and shoot. Response to propagation technique depends on varieties, and if varieties are not responsive, rooting their cuttings will be very difficult. Hormones dusted on the axils of the leaf sometimes increased the speed of root, tuber, and shoot formation, and can be considered a useful

TABLE 2.-Development of roots and shoots of D. alata variety Florido as influenced by season

\begin{tabular}{lccc}
\hline \multirow{2}{*}{$\begin{array}{c}\text { Date of } \\
\text { preparation of } \\
\text { cuttings }\end{array}$} & $\begin{array}{c}\text { Number of } \\
\text { cuttings }\end{array}$ & Percentage of cuttings \\
\cline { 3 - 4 } & 100 & 65 & $\begin{array}{c}\text { With roots } \\
\text { and shoots }\end{array}$ \\
\hline May 26 & 150 & 43 & 49 \\
June 15 & 360 & 50 & 9 \\
July 10 & 96 & 50 & 4 \\
July 22 & 135 & 62 & 11 \\
August 24 & 200 & 62 & 0 \\
September 4 & 50 & 60 & 0 \\
November 6 & & & 0 \\
\hline
\end{tabular}

TABLE 3.-Comparative rooting ability of stem cuttings from different portions of the stem of D. alata variety Florido

\begin{tabular}{lccc}
\hline & \multirow{2}{*}{$\begin{array}{c}\text { Number of } \\
\text { cuttings }\end{array}$} & Wortion of stem & Percentage of cuttings \\
\cline { 3 - 4 } & 47 & 21 & $\begin{array}{c}\text { With roots } \\
\text { and shoots }\end{array}$ \\
\hline Youngest 4th & 60 & 68 & 0 \\
Second 4th & 47 & 87 & 29 \\
Third 4th & 46 & 79 & 55 \\
OIdest 4th & &
\end{tabular}

TABLE 4.-Influence of hormonal treatment on rooting of stem cuttings of Dioscorea alata varieties Florido and Forastero

\begin{tabular}{lcccccc}
\hline \multirow{2}{*}{ Variety } & $\begin{array}{c}\text { Days after } \\
\text { treatment } \\
\text { begun }\end{array}$ & $\begin{array}{c}\text { Hormonal } \\
\text { treatment }\end{array}$ & $\begin{array}{c}\text { Number } \\
\text { of } \\
\text { cuttings }\end{array}$ & $\begin{array}{c}\text { With } \\
\text { roots }\end{array}$ & $\begin{array}{c}\text { With roots } \\
\text { and tubers }\end{array}$ & $\begin{array}{c}\text { With roots, } \\
\text { tubers, and } \\
\text { shoots }\end{array}$ \\
\hline Florido & 30 & Yes & 80 & 96 & 30 & 0 \\
Florido & 30 & No & 80 & 64 & 39 & 5 \\
Florido & 50 & Yes & 80 & 95 & 42 & 2 \\
Florido & 50 & No & 80 & 95 & 62 & 9 \\
Forastero & 30 & Yes & 80 & 75 & 35 & 4 \\
Forastero & 30 & No & 80 & 75 & 45 & 4 \\
\hline
\end{tabular}


practice. However, because of the slow growth of plants from cuttings, it appears that the technique, while initially producing many small plants rapidly, may not be as useful in multiplying special clones as the conventional multiplication from tuber pieces. The technique of propagation from stem cuttings does not appear to be suitable for use at the farm level.

\section{RESUMEN}

Técnicas sencillas desarrolladas para arraigar esquejes de ñames que contienen sapogenina se probaron con especies de tubérculos comestibles. Se desarrollaron raíces en 5 semanas cuando el esqueje estuvo en condición de arraigarse. Especies y variedades difieren con respecto a su capacidad de arraigar. Esquejes de $D$. alata se arraigan fácilmente, los de $D$. rotundata no tanto, y los de D. esculenta y D. trifida no arraigan bien. Esquejes sembrados temprano en la estación de crecimiento arraigan y producen tallos nuevos fácilmente, pero los que brotan más tarde, desarrollan un tubérculo pequeño y raíces, y frecuentemente no desarrollan tallos. Esquejes muy jóvenes o de tallos maduros no arraigan tan fácilmente como los de desarrollo intermedio.

\section{LITERATURE CITED}

1. Bluden, G., Hardman, R., and Trease, G. E., 1966. Some observations on the propagation of Dioscorea belizensis Lundell, and other steroid-yielding yams, Planta Med. 14: 84-9.

2. Correll, D. S., Schubert, B. G., Gentry, H. S., and Hawley, W. O., 1955. The search for plant precursors of cortisone, Econ. Bot. 9: 307-75.

3. Ferguson, T. U., 1972. The propagation of Dioscorea spp. by vine cuttings, Trop. Root and Tuber Crops Newsletter 5: 4-7.

4. Martin, F. W., and Delpín, H., 1969. Techniques and problems in the propagation of sapogenin-bearing yams from stem cuttings, J. Agric. Univ. P.R. 53(3): 191-8.

5. Njoku, E., 1963. The propagation of yams (Dioscorea spp.) by vine cuttings, J. West Afr. Sci. Assoc. 8(1): 29-32.

6. Preston, W. H., Jr., and Haun, J. R., 1962. Factors involved in the vegetative propagation of Dioscorea spiculiflora Hemsl. from vines, Proc. Am. Soc. Hort. Sci. 80: 417-29. 